\title{
Muhasebe Bilgilerinin Kalitesini Etkileyen Faktörler Üzerine Bir Literatür İncelemesi*
}

\author{
Nuray DEMİREL ARICI* Mahmut KARĞIN **
}

\begin{abstract}
$\ddot{O} Z$
Muhasebe bilgilerinin kalitesi, kavramsal olarak içerisinde birden fazla boyut ve ölçütü barındırdığından tek bir tanımla ifade edilmesi zor bir kavramdır. Bununla birlikte Uluslararası Muhasebe Standartları Kurulu (UMSK) konuyu faydacı bir yaklaşımla ele almaktadır. Diğer bir deyişle, bir muhasebe bilgisi kullanıcıya karar aşamasında fayda sağllyorsa kalitelidir. Kavramsal Çerçeve'de muhasebe bilgilerinin faydalı olabilmesi için sahip olması gereken niteliksel özellikler; temel (ihtiyaca uygunluk, gerçeğe uygun sunum) ve destekleyici (karşılaştırllabilirlik, doğrulanabilirlik, zamanında sunum, anlaşılabilirlik) özellikler olmak üzere iki grupta ele alınmaktadır. Bu çalışmanın amacı, muhasebe bilgilerinin kalitesini etkileyen faktörlerin araştırılmasıdır. Bu amaçla çalışmada muhasebe kalitesini etkileyen faktörler üzerine bir literatür incelemesi gerçekleştirilmiştir. Bu inceleme yapılırken muhasebe kalitesini etkileyen faktörler, ülkelere özgü faktörler ve işletmelere özgü faktörler şeklinde iki grupta sinıflandırılmıştır.
\end{abstract}

Anahtar Kelimeler: Muhasebe bilgilerinin kalitesi, ülkelere özgü faktörler, işletmelere özgü faktörler

JEL Sinıflandirmasi: $M 40$, M41

\section{A Literature Review on the Determinants of Accounting Quality}

\begin{abstract}
Since accounting quality contains conceptually more than one dimension and measure, it is difficult to be stated with only one definition. However, International Accounting Standards Board (IASB) dealt with the concept from a utilitarian approach. In other words, if accounting provides useful information to users in their decision making process, then it is well-qualified. Qualitative characteristics that are useful in terms of accounting information need to be addressed in Conceptual Framework by two groups such as fundamental (relevance and faithful representation) and enhancing (comparability, verifiability, timeliness, and understandability) ones. The aim of this study is to analyze the determinants of accounting quality. For this purpose, a literature review is executed on the subject. In this study, the determinants of accounting quality are classified by country specific factors and firm specific factors.
\end{abstract}

Key Words: Accounting quality, country specific factors, firm specific factors

JEL Classification: M40, M41

\section{Gİiș}

Bir bilgi sistemi döngüsünde, işletmelerin faaliyetlerini sürdürürken meydana gelen veriler toplanarak, bilgi işlem yöntemleriyle bilgi haline

\footnotetext{
* Bu çalışma, Nuray DEMIREL ARICI'nın Celal Bayar Üniversitesi Sosyal Bilimler Enstitüsü İşletme ABD'nda tamamladığı "Sermaye Piyasalarında Muhasebe Bilgilerinin Kalitesi: Borsa İstanbul Üzerine Bir Uygulama" adlı doktora tez çalışmasından türetilmiştir.

"Yrd.Doç.Dr., Celal Bayar Üniversitesi, İşletme Fakültesi, İngilizce İşletme Bölümü, nuray.demirel@cbu.edu.tr

** Doç.Dr., Celal Bayar Üniversitesi İ̈BF, İşletme Bölümü, mahmut.kargin@cbu.edu.tr
} 
dönüştürülmekte ve bilgi kullanıcılarına sunulmaktadır. Bilgi kullanıcıları, karar verme aşamasında kendilerine sunulan bu bilgileri kullanarak, en doğru kararları vermeye çalışmaktadır.

Tüm bilgi sistemlerinde olduğu gibi, muhasebe bilgi sisteminin amac1, kullanıcılara karar verme sürecinde yardımc olacak kaliteli bilgilerin sağlanmasıdır. İşletmelerin, bir ülkenin sahip olduğu ekonomik kaynakların çoğunluğunu ellerinde bulundurdukları düşünüldüğünde, finansal raporlarda sunulan muhasebe bilgilerinin, kullanıcıların kararlarının isabetli olmasında ve kaynakların etkin bir şekilde tahsis edilmesinde önemli bir rol oynadığ1 anlaşılabilir.

$\mathrm{Bu}$ çalışmanın amacı, muhasebe bilgilerinin kalitesini belirleyen faktörlerin araştırılmasıdır. Bu amaçla çalışmada öncelikle kaliteli muhasebe bilgisinin kavramsal çerçevesi irdelenmiş ve sahip olması gereken niteliksel özellikler açıklanmıştır. Çalışmanın devamında muhasebe bilgilerinin kalitesini etkileyen faktörler, ülkelere özgü ve işletmelere özgü olmak üzere iki grupta sınıflandırılarak olası etkileri üzerine bir literatür incelemesi gerçekleştirilmiştir.

\section{MUHASEBEDE ULUSLARARASI ORTAK BİR DİL ARAYIŞI VE MUHASEBE BILLGILERININ KALITESI}

Küreselleşme süreciyle birlikte, işletmelerin faaliyetlerinin ulusal sınırları aşması, finansal bilgilere internet aracılığıla ulaşılabilmesi, işletmelerin farklı ülke borsalarında sermaye arayışlarına girmesi ve sınır ötesi yatırım kararları gibi birçok sebep, işletmelerin dili olan muhasebenin uluslararası bir boyut kazanması gerekliliğini ortaya çıkarmıştır.

Uluslararası muhasebe standartlarının oluşturulması konusunda ilk tartışmalar, 1960'larda başlamış ve bu konunun bir örgüt (komite) tarafindan yürütülmesine yönelik öneriler, ilk defa 1972 yılında Sydney'de yapılan 10. Uluslararası Muhasebeciler Kongresi'nde gündeme gelmiştir (Başpınar, 2004: 53). Sonuç olarak, 1973 yılında Uluslararası Muhasebe Standartları Komitesi (UMS Komitesi) kurulmuş ve 2001 yılına kadar faaliyet göstererek temel Uluslararası Muhasebe Standartlarını (UMS) yayımlamıştır. 2001 yılında Uluslararası Muhasebe Standartları Kurulu (UMSK), UMS Komitesi'nin yerini alarak Uluslararası Finansal Raporlama Standartlarını (UFRS) yayımlamaya başlamıştır. UMSK'nın amacı; yatırımcılara ve diğer kullanıcılara kararlarını verirken yardımcı olacak, yüksek kaliteli, anlaşılabilir, şeffaf ve karşılaştırılabilir bilgiler sağlayan finansal tabloların hazırlanması için uluslararası alanda kabul edilebilir tek bir standartlar seti oluşturmaktır (Yallapragada, 2012: 284). Bu amaçla UMSK, işletmelerin finansal durumlarını ve performanslarını daha doğru yansitacak ilke bazlı standartlar yayımlamaktadır.

Yallapragada (2012: 284), Avrupa Birliği'nin UMS/UFRS'yi ${ }^{1} 2005$ yılında kabul etmesinin, standartların geniş bir alanda kabul görmesinde itici güç olduğunu belirtmektedir. $\mathrm{Bu}$ standartlar, yasal hiçbir zorunluluk olmamasına karşın dünya çapında yeknesaklığın sağlanmasının faydalarını dikkate alan birçok

${ }^{1}$ UMS/UFRS, çalışmanın bundan sonraki kısmında UFRS olarak ifade edilecektir. 
ülke tarafından gönüllü olarak kabul görmektedir. UFRS'lerin borsada işlem gören şirketler tarafindan ulusal finansal raporlamada kullanımı ile ilgili olarak Deloitte'in Haziran 2012 tarihi itibariyle yaptığı araştırmanın sonuçları, aşağıdaki Tablo 1'de görülmektedir.

Tablo 1. UFRS'nin Dünya'da Kullanımı

\begin{tabular}{|l|c|c|}
\hline & Ülke Sayısı & Yüzde \\
\hline UFRS'ye izin verilmiştir. & 29 & 17 \\
\hline UFRS'ye izin verilmemiştir. & 30 & 17 \\
\hline $\begin{array}{l}\text { UFRS, borsada işlem gören bazı ulusal } \\
\text { şirketler için zorunludur. }\end{array}$ & 5 & 2 \\
\hline $\begin{array}{l}\text { UFRS, borsada işlem gören tüm ulusal } \\
\text { şirketler için zorunludur. }\end{array}$ & 93 & 53 \\
\hline Ülkede borsa yoktur. & 20 & 11 \\
\hline TOPLAM & $\mathbf{1 7 7}$ & $\mathbf{1 0 0}$ \\
\hline
\end{tabular}

Kaynak: Deloitte, IFRSs in your pocket 2012, s.21-28'den derlenmiştir. https://www.iasplus.com

Araştırma 174 ülkede yapılmış olup, baz alınan tabloda bazı ülkeler için her iki seçenek birlikte işaretlenmiş olduğundan, tablodaki toplam ülke sayısı 177 olarak gerçekleşmiştir. UFRS, araştırmaya konu olan ülkelerin \%53'ünde borsada işlem gören tüm ulusal şirketler için zorunlu olarak kullanılmaktadır. Ülkelerin $\% 2$ 'sinde ise, borsada işlem gören bazı ulusal şirketler için zorunlu olarak kullanılmaktadır. Yine bu ülkelerin \%17'sinde UFRS'nin kullanımına izin verilmekle birlikte, yasal bir zorunluluk söz konusu değildir. Ülkelerin \%17'sinde standartların kullanılmasına izin verilmemiştir. Araştırmanın yapıldığ \%11'inde borsa yoktur. Genel olarak yasal zorunluluk dikkate alınmadığında, araştırmaya konu olan ülkelerin \% 72'sinde (127 ülkede) UFRS kabul görmüştür.

Uluslararası muhasebe standartlarının, işletmelerin performanslarının daha doğru yansıtılması, yöneticilerin yargı kullanımı ve karşılaştırılabilirlik açısından, muhasebe kalitesini olumlu yönde etkilemesi beklenmektedir. Barth vd. (2008: 47), muhasebe standartlarının bazı konularda önemli sonuçlar doğuracağını belirtmektedir. Bunların başında işletmelerin durumunun gerçeğe uygun sunumu ile finansal bilgi kullanıcılarına karar verme sürecinde yardımc1 olacak muhasebe bilgilerinin sağlanması, yöneticilerin muhasebe bilgilerini kendi çıkarları doğrultusunda manipüle etmelerinin sınırlandırılması ve standartların eş zamanlı kabul edilmesiyle karşılaştırılabilirliğin arttırılması gelmektedir.

Muhasebe literatürü incelendiğinde, muhasebe kalitesine ilişkin kesin, açık ve genel kabul görmüş bir tanım bulunmamakla birlikte (Gençoğlu ve Ertan, 2012: 2), hem Finansal Muhasebe Standartları Kurulunun (FMSK) hem de UMSK'nın konuya yaklaşımı, muhasebe bilgilerinin kullanıcılara karar aşamasında faydalı olması esasına dayanmaktadır. UMSK, muhasebe bilgilerinin faydalı olabilmesi için sahip olması gereken niteliksel özellikleri yayımladığ 1 Kavramsal Çerçeve'de ele almıştır. Kavramsal Çerçeve, ilgililerin kullanımı için hazırlanan ve sunulan finansal tabloların tabi olacakları usul ve esasları belirlemektedir. Finansal raporlamanın amac1, faydalı finansal bilginin niteliksel 
özellikleri, finansal tabloları oluşturan unsurların tanımı, tahakkuk ve ölçümleme esasları ile sermaye ve sermayenin devamlılığ (korunması) kavramları, Kavramsal Çerçeve'nin kapsamını oluşturmaktadır.

\section{KALITELI MUHASEBE BÍLGISININ NITELIIKSEL ÖZELLIKKLERİ}

Muhasebe bilgilerinin taşıması gereken niteliksel özellikler, Kavramsal Çerçeve'de belirlenmiştir. Niteliksel özellikler, "kullanıcılara finansal raporlarda sunulan bilgilere dayanarak işletme hakkında kararlarını alırken en çok fayda sağlayacak bilgi"yi tanımlamaktadır (Kavramsal Çerçeve, 2011, NÖ1). Kavramsal Çerçeve'de bu özellikler, temel ve destekleyici niteliksel özellikler şeklinde ikiye ayrılmıştır. Şekil 1 bu özellikleri göstermektedir.

Şekil 1. Faydalı Finansal Bilginin Niteliksel Özellikleri

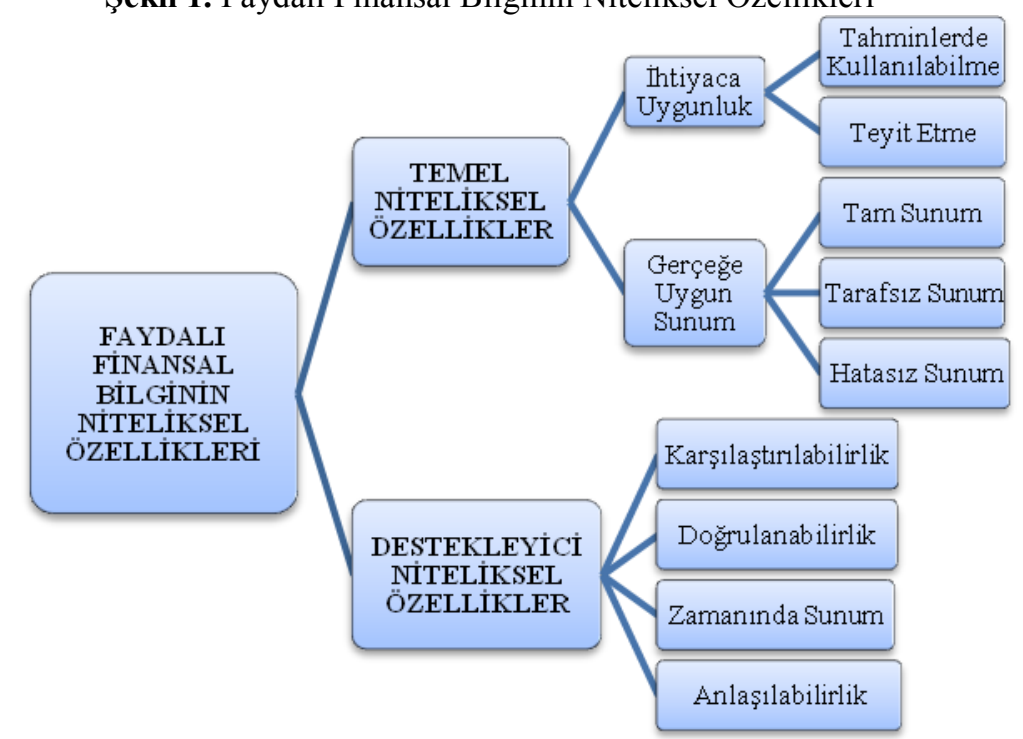

Kaynak: R. Aktaş (2013). Muhasebe Politikaları, Tahminler ve Hatalar. Gazi Kitabevi: Ankara, s.15.

\section{A. Temel Niteliksel Özellikler}

Kavramsal Çerçeve'de finansal bilginin kullanıcılarına faydalı olabilmesi için sahip olması gereken temel niteliksel özellikler, "ihtiyaca uygunluk (ilgililik)" ve "gerçeğe uygun sunum" şeklinde belirtilmiştir. Bilginin faydalı olması için, hem ihtiyaca uygun olması hem de gerçeğe uygun bir şekilde sunulması gerekir.

\section{1. İhtiyaca Uygunluk (İlgililik)}

İhtiyaca uygunluk, finansal tablolardan elde edilen bilgilerin kullanıcıların kararları ile ilişkili ve kullanım amacına uygun olmasını ifade etmektedir. Akdoğan ve Tenker (2006: 34), muhasebe bilgilerinin kullanıcıların karar verme ihtiyaçlarını karşılayabilecek nitelikte olması gerektiğini belirtmektedir. Bununla birlikte geniş bir kullanıcı kitlesine sahip finansal tabloların özel amaçlı olmaktan ziyade, bu kitlenin ortak ihtiyaçlarını karşılayacak şekilde genel amaçlı olması gerekmektedir. 
Kavramsal Çerçeve'ye göre bir finansal bilgi, kullanıcıların kararlarını etkileyebiliyorsa ihtiyaca uygundur. Ĕger finansal bilgi; tahminlerde kullanilabilme, teyit etme veya her iki özelliğe birden sahipse, kullanıcıların kararlarını etkileme gücüne sahiptir.

İhtiyaca uygunluk özelliğinin bir diğer unsuru da önemlilik ilkesidir. Bu ilke finansal tablolardaki kalemlerin büyüklüğü ile ilgilidir. Örten vd. (2008: 6), önemliliğin finansal tablonun niteliksel özelliklerinden olmaktan daha çok, bir ayrım ya da ayrışma noktasını gösterdiğini ifade etmektedir. Kavramsal Çerçeve'de, bir bilginin verilmemesi veya yanlış verilmesi, kullanıcıların belirli bir işletmeye ilişkin finansal bilgiye dayanarak verecekleri kararları etkileyebiliyorsa, bu bilginin önemli olduğu belirtilmektedir.

\section{Gerçeğe Uygun Sunum}

Kavramsal Çerçeve'ye göre finansal bilginin kullanicılara faydalı olabilmesi için, finansal raporların yalnızca ihtiyaca uygun bilgileri sunması yeterli değildir. Ayrıca açıklamayı amaçladığı ekonomik olayları, gerçeğe uygun bir şekilde sunmalıdır. Gerçeğe uygun bir sunumun, tam anlamıyla sağlanabilmesi için üç özelliğe sahip olması gerekir. Buna göre sunum tam, tarafsız ve hatasız olmalıdır.

\section{B. Destekleyici Niteliksel Özellikler}

Destekleyici niteliksel özellikler, finansal bilginin faydalılığını arttıran özelliklerdir. Kavramsal Çerçeve'de bu özellikler; karşılaştırılabilirlik, doğrulanabilirlik, zamanında sunum ve anlaşılabilirlik olarak sıralanmıştır.

\section{Karşılaştırılabilirlik}

Kullanıcıların gerek bir işletmenin finansal durumu, faaliyet sonuçları ve nakit akışlarında zaman içinde yaşanan değişimleri, gerekse bu işletmenin başka bir işletmeye nispeten durumunu değerlendirebilmesi için finansal tabloların karşılaştırılabilir nitelikte olması gerekmektedir. Kavramsal Çerçeve'de karşılaştırılabilirlik, kullanıcıların kalemler arasındaki benzerlikleri ve farklılıkları belirleyebilmesini ve anlayabilmesini sağlayan niteliksel bir özellik olarak ifade edilmiştir.

Gençoğlu (2007: 25), karşılaştırılabilirlik özelliğinin önemli bir şart1 olarak, kullanıcıların finansal tabloların hazırlanmasında takip edilen muhasebe politikaları, bu politikalarda yapılan değişiklikler ve bu değişikliklerin etkileri hakkında bilgilendirilmeleri gerektiğini öne sürmektedir. Kullanıcılar, hem bir işletmenin takip ettiği muhasebe politikalarında dönemler itibariyle herhangi bir değişiklik olup olmadığını, hem de diğer bir işletmenin kullandığı muhasebe politikaları ile farklılıklar olup olmadığını bilmelidirler.

\section{Doğrulanabilirlik}

Kavramsal Çerçeve'de doğrulanabilirlik, farkl bilgi düzeyindeki ve bağımsız gözlemcilerin belirli bir ekonomik olayın gerçeğe uygun sunulduğu hususunda görüş birliğine varabilmeleri (gözlemcilerin tam bir uzlaşmaya varmalart gerekmez) şeklinde ifade edilmektedir. Söz konusu doğrulama, doğrudan ya da dolaylı olabilir. Doğrudan doğrulama, nakit tutarının sayılması gibi doğrudan yapılan gözlem ile bir tutarın ya da diğer bir sunumun 
doğrulanması anlamına gelir. Dolayl doğrulama ise, bir modelde, formülde ya da diğer bir yöntemde kullanılan verilerin kontrol edilmesi ve ayn yöntem kullanılarak sonuçların yeniden hesaplanması anlamındadır.

\section{Zamanında Sunum}

Kavramsal Çerçeve'ye göre zamanında sunum, bilginin karar verenler açısından kararlarını etkileyebileceği zamanda mevcut olması anlamına gelmektedir. Genellikle, bilgi eskidikçe faydası da azalmaktadır. Ancak bazı bilgiler, bazı kullanıclların eğilimleri belirlemeye ve değerlendirmeye ihtiyaç duyması gibi nedenlerle raporlama dönemi sona erdikten uzun süre sonra da kullanışl olmaya devam edebilir. Demir (2010: 146), zorunlu olmayan nedenlerle raporlamanın geciktirilmesinin, bilginin ihtiyaca uygunluk özelliğini ortadan kaldırdığını öne sürmektedir.

\section{Anlaşılabilirlik}

Finansal bilgilerin kullanıcılara yararlı olabilmesi için, bu bilgilerin anlaşılabilir olması gerekmektedir. Sunulan bilgilerin, kullanıcılar tarafından anlaşılamaması, bilginin yararını ortadan kaldırmaktadır. Ancak Örten vd. (2008: 6), kullanıcılar açısından yararlı olacak nitelikteki bilgilerin, bazı kullanıcılar tarafından anlaşılması güç olarak nitelendirilip, finansal tablolar dışında tutulamayacağını vurgulamaktadırlar.

Kavramsal Çerçeve'ye göre bilginin açık ve öz olarak sinıflandırılması, tanımlanması ve sunulması onu anlaşılır kılmaktadır. Bazı ekonomik olaylar, doğası gereği karmaşıktır ve basitleştirilemezler. Finansal raporlar, işletme faaliyetleri ve ekonomik faaliyetler hakkında makul seviyede bilgisi olan, bilgileri dikkatle gözden geçiren ve analiz eden kullanıcılar için hazırlanmaktadır. Bazen bilgili ve dikkatli kullanıcılar bile, karmaşık ekonomik olaylara ilişskin bilgileri anlamak için bir danışmandan yardım alma ihtiyacı duyabilirler.

Finansal bilginin toplanması, işlenmesi, doğrulanması ve yayımlanması sürecinin belli bir maliyeti söz konusudur. Bu nedenle faydalı finansal bilginin sunumunda, maliyet kısıtı ön plana çıkmaktadır. Kavramsal Çerçeve'ye göre, bilginin faydalı ve değerli olabilmesi için raporlandığında sağladığı faydanın, neden olduğu maliyeti aşması gerekmektedir.

\section{MUHASEBE BÍLGILERININ KALITESINI ETKILEYEN FAKTÖRLER}

Muhasebe bilgilerinin kalitesini etkileyen çok sayıda faktör bulunmaktadır. Bu faktörler enflasyon, finansal krizler gibi ekonomik faktörler; muhasebe ve denetim standartları, kurumsal yönetim, piyasaların gelişmişlik düzeyi, ülkedeki etik anlayışı, kültür, muhasebe mesleğinin gelişmişlik düzeyi, eğitim gibi kurumsal faktörler ile işletme büyüklüğü, faaliyet riski, finansal risk gibi firmalara özgü faktörler şeklinde sınıflandırılabilir.

Soderstrom ve Sun (2007: 688), muhasebe kalitesini; hukuki ve politik sistem, muhasebe standartları ve finansal raporlama güdülerinin etkisi ile şekillenen çok boyutlu bir kavram olarak ifade etmektedirler. Şekil 2 muhasebe bilgilerinin kalitesini etkileyen faktörleri göstermektedir. 
Şekil 2. Muhasebe Bilgilerinin Kalitesini Etkileyen Faktörler

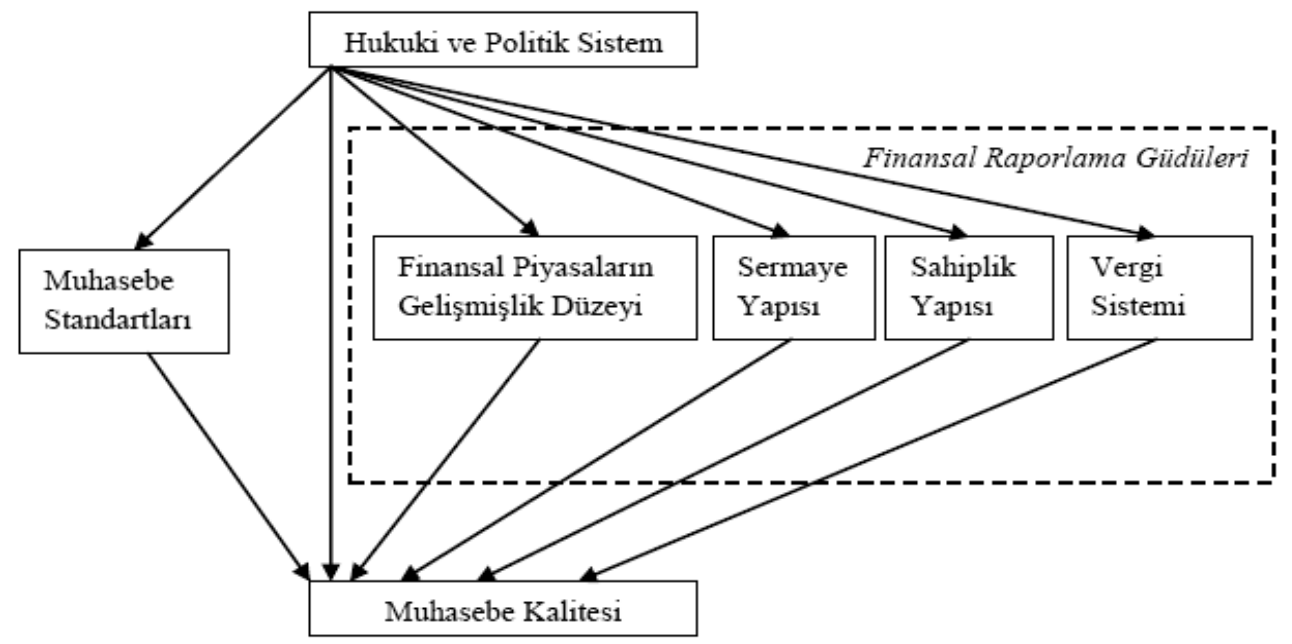

Kaynak: N.S. Soderstrom and K.J. Sun (2007). IFRS Adoption and Accounting Quality: A Review. European Accounting Review, 16(4), p.688.

Şekil 2'de sunulduğu gibi; muhasebe standartları, finansal piyasaların gelişmişlik düzeyi, sermaye yapısı, sahiplik yapısı ve vergi sistemleri, muhasebe kalitesi üzerinde doğrudan bir etkiye sahiptir. Hukuki ve politik sistem ise, hem muhasebe kalitesini doğrudan etkilemekte hem de muhasebe kalitesini etkileyen faktörleri etkileyerek muhasebe kalitesi üzerinde dolaylı bir etki yaratmaktadır. Bu çalışmada muhasebe kalitesini etkileyen faktörler, ülkelere özgü faktörler ve işletmelere özgü faktörler şeklinde iki grupta incelenmiştir.

\section{Faktörler}

\section{A. Muhasebe Bilgilerinin Kalitesini Etkileyen Ülkelere Özgü}

Bir ülkenin hukuki ve politik sistemi, ülkede kullanılan muhasebe standartları ve uygulamaları, finansal piyasalarının gelişmişlik düzeyi, ülkedeki vergi sistemi, ülkenin kurumsal yapısı, kültür, eğitim seviyesi gibi birçok faktör ülkede sunulan muhasebe bilgilerinin kalitesini doğrudan ya da dolaylı olarak etkilemektedir. $\mathrm{Bu}$ faktörlerden bir kısmı bu bölümde ayrıntılı olarak incelenmiştir.

\section{Hukuki ve Politik Sistem}

Hukuki ve politik sistemler, muhasebe kalitesini hem doğrudan, hem de muhasebe standartları ve finansal raporlama güdüleri (finansal piyasaların gelişmişlik düzeyi, sermaye yapısı, sahiplik yapısı ve vergi sistemi) aracılığıyla dolaylı olarak etkilemektedir. Hukuki ve politik sistemlerin doğrudan etkileri bu başlık altında ele alınırken, dolaylı etkileri diğer başlıklar altında incelenecektir.

Hukuk sistemleri; sisteme hakim olan biçim, öncelikler ve ilkeler doğrultusunda Kıta Avrupası hukuk sistemi (Roma hukuku), Anglo-Sakson hukuk sistemi (Ortak hukuk), İslam hukuk sistemi ve Sosyalist hukuk sistemi şeklinde sinıflandırılmaktadır (www.wikipedia.org). Burada Kita Avrupası ve Anglo- 
Sakson hukuk sistemlerinin temel özellikleri incelenerek, muhasebe kalitesi üzerindeki etkileri üzerine tartışılacaktır.

Kıta Avrupası hukuk sistemine sahip ülkelerde; kanunlar, yasa koyucu tarafindan ayrıntılı olarak düzenlenmektedir. Kanunların uygulanmasında ve değişen koşullar karşısında, hakimin takdir yetkisinin alanı sınırlıdır. AngloSakson hukuk sisteminde ise; kanunlar, sosyal ve ekonomik değişimlere bağlı olarak oluşmaktadır. Hakimin genel ilkeler çerçevesinde takdir yetkisinin genişliği, hukuk sisteminin dinamik bir şekilde değişen koşullara uyum sağlamasını mümkün kılmaktadır (Aktaş, 2009: 40).

Kıta Avrupası ülkelerde, Japonyada ve Fransızca konuşan Afrika ülkelerinde, işletmeler bankalarla çok yakın ilişki içerisindedirler. İşletmeler, sermaye temininde daha çok bankalardan faydalanmaktadırlar. Muhasebe, yasa ve kurallara uygun olarak yönlendirilmektedir. Bu ülkelerde muhasebe uygulamaları, kullanıcıların karar verme süreçlerine yönelik bilgilerin sunulmasından ziyade, tam tersine devlet-vergi temelinde ve makro ekonomik planlar üzerine kuruludur. Anglo-Sakson ülkeler ise, çok büyük sermaye ve hisse senedi piyasalarına sahiptirler. Sermaye temininde, bu piyasalar önemli rol oynamaktadır. Muhasebe bilgilerinin sunumunda amaç, kullanıcıların karar verme sürecinde ihtiyaç duydukları bilgilerin sağlanmasıdır (Gökdeniz, t.y: 24).

Hukuki sistemler, muhasebe standartlarının uygulanmasını yasal olarak zorunlu tutmak suretiyle muhasebe kalitesini doğrudan etkilemektedir. Uluslararası muhasebe literatüründe, Anglo-Sakson hukuk sistemine sahip olan ve ortaklık haklarının yüksek düzeyde korunduğu ülkelerde, muhasebe kalitesinin daha yüksek olduğu tespit edilmiştir. Anglo-Sakson hukuk sistemine sahip ülkelerde, muhasebe standartlarının uygulanması konusunda yasal yaptırım gücü daha yüksektir. Kıta Avrupası hukuk sistemine sahip ülkelerde ise, yaptırım gücü menkul kıymet borsalarına bağlı olmaktadır. Çünkü UMSK, UFRS'leri yayınlamakta ancak uygulanması yönünde herhangi bir yaptırım gücüne sahip bulunmamaktadır.

Ülkelerin hukuki sistemleri farklı olduğundan, muhasebe kalitesinin ülkeler arasında farklıl1k göstermesi beklenen bir durumdur. Bununla birlikte, UFRS ilke bazlı standartlardır yani denetimciler ve muhasebeciler, detayl kurallar yerine genel ilkeleri takip etmekte ve bu ilkeleri özel durumlara uyarlamak durumunda kalmaktadırlar. İlkelerin yorumlanmasında hukuki sistemin üstlendiği rol, muhasebe kalitesini etkilemektedir. Ortaklık haklarının yüksek düzeyde korunduğu ülkelerde, ilkelerin yorumunun bilginin hissedarlara gerçeğe uygun sunumunu sağlayacak şekilde olması beklenir. Kreditör haklarının korunduğu ülkelerde ise, ilkelerin yorumunun varlıkların kaydedilmesinde ihtiyatlılık, yükümlülüklerin kaydedilmesinde agresif yaklaşımın kullanılması yoluyla bankaların anlaşma taleplerini karşılayacak şekilde olması beklenir (Soderstrom ve Sun, 2007: 690).

Muhasebe kalitesini doğrudan etkileyen bir diğer faktör, politik sistemlerdir. Yozlaşmış politik sistemlere sahip ülkelerde işletme sahipleri ve yöneticileri, devlet ihalelerini kazanmak, daha az vergi vermek ve piyasada 
monopol olabilmek gibi amaçlarla politikacılara rüşvet verme eğiliminde olmaktadırlar. İşletmeler, verilen rüşvetleri finansal tablolarında gizlemek için politik ve sosyal denetimden kaçınmaktadırlar. Dahası, devlet müdahalesinin yaşanma ihtimalinin yüksek olduğu ülkelerde işletmeler, bu durumla karşılaşmamak için karlarını yüksek göstermekten kaçınmaktadırlar. Bu durum, muhasebe kalitesini olumsuz yönde etkilemektedir (Soderstrom ve Sun, 2007: 690-691).

\section{Muhasebe Standartları}

Muhasebe standartları, muhasebe bilgilerinin kalitesini doğrudan etkilemektedir. Bostanc1 (2002), muhasebe standartların1, finansal tablo kullanıcılarının ihtiyaç duyduğu işletme sonuçlarının; doğru, gerçeğe uygun, karşılaştırılabilir, tutarlı, güvenilir ve anlaşılabilir olarak yansıtılabilmesi için uyulması gereken ilke ve kurallar bütünü olarak tanımlamaktadır.

Uluslararası finansal raporlama standartlarının dünya çapında kabulü oldukça hızlı bir şekilde gerçekleşmiştir. Holthausen (2008: 2), bu durumun, dünya çapında geçerli olacak tek bir dizi finansal raporlama standardının muhasebe kalitesini arttıracağı, farklı ülkelerdeki işletmelerin raporlarını birbirleriyle karşılaştırmanın daha kolay ve şeffaf bir şekilde yapılabileceği beklentisinden kaynaklandığını ileri sürmektedir. Jun-bo ve Hai-Zhong (2011: 701), genel olarak UFRS'nin kabulünün, firmaların finansal tablolarının karşılaştırılabilir olmasını sağlayarak bilgi ve işlem maliyetlerini azaltacağını ve bu durumun hisse senedi piyasalarında pozitif bir tepkiye yol açabileceğini belirtmektedirler.

Nitekim uluslararası muhasebe literatüründe, genellikle uluslararası muhasebe standartlarının kabulü ile muhasebe kalitesi arasında pozitif bir ilişki tespit edilmiştir. Soderstrom ve Sun (2007: 688), UMSK'nın muhasebe standartlarının kalitesini geliştirmeye devam ettikçe, bu standartlara dayanılarak yapılan finansal raporlamanın daha ilgili (ihtiyaca uygun) ve güvenilir olacağ yönündeki beklentinin yüksek olduğunu dile getirmektedirler. Bununla birlikte ülkelerin kurumsal ve ekonomik faktörleri birbirinden farkl1lık göstermektedir. $\mathrm{Bu}$ faktörlerin birbirine benzer hale getirilmesi, maliyet ve zaman açısından imkansıza yakın bir durumdur. Holthausen (2008: 2) de, bu nedenle UFRS'nin kabulünden sonra dahi, muhasebe kalitesinin her ülkede aynı düzeyde olmasını beklemenin rasyonel bir beklenti olmadığını vurgulamaktadır.

Muhasebe standartlarının oluşum süreci, ülkelerin hukuki ve politik sistemlerinden etkilenmektedir. Anglo-Sakson hukuk sistemine sahip ülkelerde standartlar, muhasebe meslek mensuplarının temsil edildiği bağımsız meslek kuruluşları tarafından oluşturulurken; Kıta Avrupası hukuk sistemine sahip ülkelerde, standartlar ağırlıklı olarak kamu kurumlarının temsil edildiği ve belirleyici olduğu komiteler tarafından hazırlanmaktadır (Aktaş, 2009: 40-41). Bu ülkelerde düzenlemeler, devletin önceliklerinden etkilendiği ve siyasi partilerin politik etkileri muhasebeye yansıdığı için eleştirilmektedir (Akgül ve Akay, 2004: 6; Gökçen vd., 2006: 2). 
Soderstrom ve Sun (2007: 695-696)'a göre muhasebe kalitesi, muhasebe standartlarının kabulüyle bir düzeye kadar sağlanmıştır. Bununla birlikte daha ileri düzeyde bir iyileşmenin, ülkelerin hukuki ve politik sistemleri ile finansal raporlama güdülerindeki değişikliklere bağlı olduğunu belirtmektedirler. Ancak bir ülkenin bütün bir kurumsal yapısının değişmesi oldukça güçtür. Bu nedenle muhasebe kalitesinin geliştirilmesi için, finansal raporlama güdüleriyle ilgilenilmesi daha az maliyetli olacaktır.

\section{Finansal Piyasaların Gelişmişlik Düzeyi}

Finansal piyasalar, fon arz ve talebinin karşılaştığı piyasalardır. $\mathrm{Bu}$ piyasaların gelişmişlik düzeyi, muhasebe bilgilerinin kalitesini doğrudan etkilemektedir. Gelişmiş sermaye piyasalarına sahip ülkelerde, sermaye çok sayıda küçük yatırımcı tarafından sağlanmaktadır. Isidro ve Raonic (2012: 416)'e göre, böyle bir ortamda muhasebe bilgileri, genellikle daha doğru ve şeffaf olmaktadır. Diğer yandan işletmeler, kendilerine finansman sağlayacak daha geniş bir yatırımcı kitlesini cezbedebilmek için yüksek kaliteli bilgiler raporlama konusunda daha istekli olmaktadırlar.

Fonların ağırlıklı olarak bankalardan borçlanma yoluyla sağlandığ 1 ülkelerde ise, işletmelerle bankalar arasında yakın bağlar bulunmaktadır. Gençoğlu ve Ertan (2012: 10)'a göre bankalar, bu bağlar sayesinde işletmelerin performansları ve geleceğe dair planları ile ilgili stratejik bilgilere doğrudan ulaşabilmekte ve bu nedenle finansal tablolardaki bilgilere, nispeten daha az ihtiyaç duymaktadırlar. Dolayısıyla yöneticilerin kamuya bilgi açıklama doğrultusundaki güdüleri azalmaktadır.

Ülkelerin hukuki ve politik sistemleri, finansal piyasaları etkilemek suretiyle muhasebe kalitesini dolaylı olarak etkilemektedir. Soderstrom ve Sun (2007: 692), yatırımcıların iyi düzeyde korunmasının ve devlet müdahalesinin düşük düzeyde olmasının, yatırımcılara yatırımları üzerinden getiri elde etmeyi garanti ettiğini ve bu durumun finansman sağlamak isteyen yatırımcı sayısını arttırdığını öne sürmektedirler.

\section{Vergi Sistemleri}

Muhasebe kalitesini etkileyen önemli bir faktör de vergi sistemleridir. Gençoğlu ve Ertan (2012: 12), muhasebe uygulamaları ile vergi düzenlemeleri arasında yakın bir ilişki bulunmasının, muhasebe kalitesini düşürdügünü ifade etmektedirler. Vergi yasaları, hükümet için vergi toplamak gibi politik amaçlara hizmet etmekte, yatırımcılar için bilgi kalitesinin sağlanmasıyla ilgilenmemektedir. Ayrıca vergi oranının yüksek olması, işletmelerin vergilendirilebilir geliri düşük hesaplama doğrultusunda hareket etmelerine neden olarak muhasebe kalitesini düşürebilmektedir.

Hukuki ve politik sistemler, vergi sistemleri aracıllğıyla muhasebe kalitesini dolaylı yoldan etkilemektedir. Soderstrom ve Sun (2007: 695), Kita Avrupas1 hukuk sistemine sahip ülkelerde finansal raporlamanın, devlete yapılacak vergi ödemelerinin bir ölçüsü olarak kullanılırken, Anglo-Sakson hukuk sistemine sahip ülkelerde bilgi asimetrisini azaltmak için kullanıldığını belirtmektedirler. 


\section{B. Muhasebe Bilgilerinin Kalitesini Etkileyen İşletmelere Özgü Faktörler}

Muhasebe bilgilerinin kalitesinin işletmelere özgü faktörlerden etkilenmesi muhtemeldir. Literatürde bu faktörlerin etkileri değer ilişkisi ${ }^{2}$, karların kalitesi (sürekliliği) ${ }^{3}$ ve nakit akışlarının tahmin edilebilirliği ${ }^{4}$ boyutları üzerinden tartış1lmaktadır. ${ }^{5}$

\section{Sermaye Yapıları}

İşletmelerin varlıklarını ve faaliyetlerini finanse etmek için kullandıkları fonların bileşimine, sermaye yapısı adı verilmektedir. Sermaye yapısı, temelde iki bileşenden oluşmaktadır. Bunlardan biri, gerek hisse senedi ihracı gerekse dağıtılmayan karlar aracılığıyla arttırılabilen özkaynaklar, diğeri ise yabancı kaynaklar yani borçlanmadır.

Sermaye piyasalarında yatırımcılar, yatırım kararlarını verirken temel olarak işletmelerin finansal raporlarını dikkate almaktadırlar. Bu nedenle sermaye piyasalarından finansman sağlamak isteyen işletmelerin, daha kaliteli finansal raporlama yapması beklenen bir durumdur. Ağırlıklı olarak borçlanma yoluyla finansman sağlamayı tercih eden işletmelerde ise, finansal raporlama güdüsünün nispeten daha zayıf olduğu söylenebilir.

İşletmelerin sermaye yapıları, hukuki ve politik sistemlerden etkilenmektedir. Kreditörlerin yüksek düzeyde korunduğu ülkelerde işletmeler, bankalardan daha düşük maliyetle daha kolay finansman sağlayabilmektedirler. Soderstrom ve Sun (2007: 693), devlet müdahalelerinin ve yolsuzlukların sıklıkla gerçekleştiği ülkelerde anlaşmaların, denetimlerden kaçınmak için gizli olarak tamamlandığını ve finansal raporlamanın, bilgi asimetrisini azaltma fonksiyonunu yerine getiremediğini belirtmektedirler. Ayrıca banka finansmanının yaygın olarak kullanıldığı ve politik risklerin yüksek olduğu ülkelerde, muhasebe kalitesinin daha düşük olduğunu ileri sürmektedirler.

\section{Sahiplik Yapıları}

Az sayıda ve büyük paya sahip ortaklardan oluşan işletmeler, yoğunlaşmış sahiplik (concentrated ownership) yapısına sahiptirler. Yoğunlaşmış sahiplik yapısının muhasebe kalitesi üzerindeki etkisi konusunda Fan ve Wong (2002: 402-403), Han (2005: 4-5) ve Cascino (2010: 3-4) iki teoriden söz etmektedirler.

Birinci teoriye göre; yoğunlaşmış sahiplik yapısı, muhasebe bilgilerinin kalitesini arttırmaktadır. Çünkü bu tarz işletmelerde büyük paya sahip ortaklar, yönetim kademelerinde yer aldıklarından işletme sahipleri ile yöneticiler

\footnotetext{
${ }^{2}$ Değer ilişkisi, muhasebe bilgilerinin kullanıcılara faydalı olması yaklaşımından hareketle özet bilanço (defter değeri) ve gelir tablosu (kar) kalemlerinin hisse senedi fiyatları/getirileri üzerindeki rolünü ifade etmektedir.

${ }^{3}$ Karların kalitesi (sürekliliği), cari karın nakit akışları ve tahakkuklar şeklinde iki bileşene ayrılarak ya da bileşenlerine ayrılmadan gelecek dönem karları ile ilişkilerinin boyutunu ifade etmektedir.

${ }^{4}$ Nakit akışlarının tahmin edilebilirliği: cari nakit akışları ve karlar ile gelecek dönem nakit akışları arasındaki ilişkiyi ifade etmektedir.

${ }^{5}$ Muhasebe bilgilerinin kalite boyutları hakkında detaylı bilgi için bkz. Karğın ve Arıcı (2015).
} 
arasındaki temsil sorunları ${ }^{6}$ azalmaktadır. Ayrıca bu işletmelere ait az sayıda hisse senedi piyasada dolaştığından piyasa baskıları daha az hissedilmektedir. Dolayısıyla bu durum yöneticilerin, işletmenin gerçekleşen ekonomik performansını farklı gösterecek şekilde muhasebe bilgilerini raporlama güdüsünü azaltarak, finansal raporlama kalitesini arttırmaktadır.

İkinci teoriye göre ise; yoğunlaşmış sahiplik yapısı, işletmelerin muhasebe bilgilerinin kalitesini azaltmaktadır. Bu teoride, belli bir eşiğin üzerinde yoğunlaşmış sahiplik yapısının, azınlığın haklarının sömürülme riskini arttırdığ 1 öne sürülmektedir. Yoğunlaşmış sahiplik yapısına sahip işletmeler, gerçek muhasebe bilgilerini işletme içinde tutmaya eğilimli olduklarından, raporlanan muhasebe bilgilerinin kalitesi düşük olmaktadır.

Ülkemizde yoğunlaşmış sahiplik yapısı, aile şirketleri şeklinde karşımıza çıkmaktadır. Bu şirketlerde aile üyeleri, genellikle yönetim kademelerindeki önemli pozisyonları ve yönetim kurullarını ellerinde bulundurmaktadırlar. Wang (2006: 620-622), yoğunlaşmış sahiplik yapısının muhasebe bilgilerinin kalitesi üzerindeki etkisini, aile şirketleri açısından yorumlamıştır.

İlk yaklaşıma göre, aile şirketlerinde kontrol gücü bulunan sahipler tarafından işletme üzerinde daha iyi bir gözetim sağlandığından, muhasebe bilgi kalitesinin yüksek olması beklenmektedir. Aile şirketlerinde, yönetimi ellerinde bulunduran aile üyelerinin firmadaki varlıkları, uzun vadeli olmaktadır. Halbuki aile şirketi olmayan diğer firmalarda yönetim, genellikle profesyonel yöneticilere bırakılmaktır. Profesyonel yöneticiler, kısa vadeli amaçlarla kendi çıkarlarını hissedarların çıkarları pahasına maksimize edecek şekilde karları manipüle edebilmektedirler. Buna karşılık aile üyeleri, hem firmanın gelecek nesillere taşınabilmesi, hem de aile itibarının korunması gibi güdülerle karların manipüle edilmesinin getireceği kısa vadeli faydalardan daha kolay vazgeçebilmektedirler. $\mathrm{Bu}$ nedenle aile şirketlerinin, diğer firmalara göre daha kaliteli finansal bilgi raporlamaları muhtemeldir.

Alternatif yaklaşımda ise, yoğunlaşmış sahiplik yapısına sahip aile şirketlerinin, karları fursatçı bir yaklaşımla yönetmeye eğilimli oldukları düşüncesi hakimdir. Aile üyeleri önemli yönetim pozisyonlarında ve yönetim kurullarında bulunduklarından, ikinci derecede kurumsal yönetime sahip olabilirler. Ayrıca aile üyeleri ile diğer hissedarlar arasında bilgi asimetrisi olma ihtimali çok yüksektir. Çünkü yoğunlaşmış sahiplik yapısı, muhasebe bilgilerinin dış yatırımcılara akışını sınırlandırmaktadır. Bilgi asimetrisi, muhasebe açıklamalarının şeffaflığını azaltmaktadır. Sonuç olarak, aile üyeleri özel amaçları için muhasebe karlarını manipüle etme güdüsüne ve imkanına sahiptirler. $\mathrm{Bu}$ görüşe göre, aile şirketleri ile düşük kaliteli finansal raporlama arasında pozitif bir ilişki söz konusudur.

Ülkelerin hukuki sistemleri, işletmelerin sahiplik yapılarını etkilemektedir. Yatırımcıların yüksek düzeyde korunduğu ülkelerde, sahiplik

\footnotetext{
${ }^{6}$ Temsil sorunu: İşletme yöneticileri ile işletmenin ortakları arasında ortaya çıkan çıkar çatışmasıdır. Ortaklar adına karar alan yöneticilerin, kararlarında ortakların menfaatlerini gözetmemesi, temsil sorununa yol açmaktadır (Sayılgan, 2006:15).
} 
yapısının yoğunluğu düşmekte yani firmalar çok sayıda ve küçük paylara sahip ortaklardan oluşmaktadır. Politik sistemler de, sahiplik yapısını etkilemektedir. Soderstrom ve Sun (2007: 694), politik rant arayışının hakim olduğu ülkelerde, yoğunlaşmış sahiplik yapısının arttığını ve bu yapının, politikacılara daha cazip geldiğini ileri sürmektedir. Çünkü bu tarz işletmelerde gizli lobi faaliyetlerinin ve rüşvetlerin firma dışına sızma ihtimali daha düşüktür. Ayrıca kontrole hakim olan işletme sahibi, çok sayıda ortağa sahip olan işletmelerdeki profesyonel yöneticilere göre daha güvenli bir pozisyona sahiptir. Bu güvenlik, politikacılarla olan ilişkide işletmeye güvenilirlik sağlamaktadır.

\section{Firma Büyüklüğ̈̈}

Firma büyüklügü, muhasebe bilgilerinin kalitesini etkileyen önemli faktörlerden birisidir. Bununla birlikte firma büyüklüğünün etkisini araştıran çalışmaların sonuçları birbirinden farklıdır.

Hayn (1995) ve Collins vd. (1997), küçük firmalarda piyasa değerinin belirlenmesinde defter değerinin rolünün, karlara göre daha önemli olduğunu ileri sürmektedirler. Bunun nedeni, küçük firmalarda finansal riskin ve zarar açıklama olasılığının büyük firmalara göre yüksek olmasıdır. Brimble ve Hodgson (2007), büyük firmaların hisse senedi değerini etkileyen muhasebe dışı bilgileri daha fazla kamuya açıkladıklarını, küçük firmaların ise genellikle işe yeni başladıklarından, zarar açıklama olasılıklarının fazla olduğunu, bu nedenle küçük firmalarda piyasa değerinin belirlenmesinde muhasebe bilgilerinin rolünün daha önemli olduğunu öne sürmektedirler. Diğer taraftan Hodgson ve Clarke (2000) ile Chandrapala (2013) büyük firmalarda değer ilişkisinin, küçük firmalara göre daha yüksek olduğuna dair kanıtlar bulmuşlardır.

Karların sürekliliği açısından bakıldığında Hayn (1995) küçük firmalarda karların sürekliliğinin düşük olduğunu ileri sürmektedir. Bu durumun, küçük firmaların finansal riskinin ve zarar açıklama olasılıklarının büyük firmalara nispeten daha yüksek olmasından kaynaklandığını belirtmektedir.

Baginski vd. (1999: 107) ise, literatürde firma büyüklügünün kar kalitesine etkisi konusunda iki önerme olduğunu ileri sürmektedirler. Birinci önermeye göre, büyük firmaların büyüme oranları, küçük firmalara nispeten çok fazla değişiklik göstermemektedir. Büyük firmalar, daha yavaş ve istikrarlı büyümektedirler. Zira büyük firmalar, istikrarlı büyümelerini sağlayacak çeşitli finansal kaynaklara sahiptirler ve bu durum karların sürekli olmasını sağlamaktadır. İkinci önerme ise, büyük firmaların karlarındaki olası dalgalanmaları, fiyat artışlarıyla kontrol edebilecekleri ve böylece küçük firmalara göre daha sürekli bir kar akışı sağlayabilecekleri şeklindedir. Shirazipour vd. (2013) de, büyük firmaların karların sürekliliği konusunda daha istikrarlı olduklarına dair kanıtlar sunmuştur.

Literatürde firma büyüklüğünün, nakit akışlarının tahminine katkı sağlayan bir faktör olduğu anlaşılmaktadır. Baginski vd. (1999)'ne göre, büyük firmalar küçük firmalara göre daha yavaş ve istikrarlı büyüdüklerinden, hem karların daha sürekli olması hem de nakit akışlarının tahmin edilebilir olması beklenir. Benzer şekilde Aktaş ve Karğın (2012), büyük firmalarda nakit 
akışlarının, küçük firmalara nispeten daha iyi tahmin edilebildiğine dair bulgular elde etmişlerdir.

\section{Finansal Risk}

Finansal risk, bir işletmede aktiflerin hangi oranda borçlarla finanse edildiğiyle ilgilidir. İşletmenin finansal kaldıraç oranı (toplam borç/toplam aktifler) yükseldikçe finansal riskin arttığı kabul edilir (Okka, 2005: 90). Finansal riskin boyutu, firmaların faiz ve ana para ödemelerinin yüksekliğini ve firmaların ödeme güçlüğüne düşme hatta iflas etme olasılıklarını göstermektedir. Ancak diğer yandan finansal riski yüksek olan firmaların gelecek dönemlerde karlılıklarının artması da olasılık dahilindedir. $\mathrm{Bu}$ nedenle finansal riskin boyutunun değer ilişkisine etkisi, yatırımcıların riske karşı sergiledikleri davranışa göre değişiklik gösterebilir. Shirazipour vd. (2013), finansal riski düşük firmaların karlarının daha sürekli olduğuna dair bulgular elde etmişlerdir. Ayrıca finansal risk düzeyinin artması, nakit akışlarının tahmin edilebilirliğini bozabilmektedir. Özetle, finansal riskin yüksek olmasının genel anlamda muhasebe bilgilerinin kalitesini olumsuz yönde etkilediği söylenebilir.

\section{Faaliyet Riski}

Faaliyet riski, bir firmada sabit maliyetlerin toplam maliyetler içerisindeki payını ifade eder. Eğer bir firmada toplam maliyetlerin büyük bir bölümü sabit ise, bu firmanın faaliyet riski yüksektir. Ceylan ve Korkmaz (2006: 139), faaliyet riski büyük olan firmalarda satışlardaki küçük bir değişikliğin karlar üzerinde büyük dalgalanmalara neden olabileceğini belirtmektedirler. Bu durum, sermaye yoğun işletmelerde söz konusu olmaktadır.

Baginski vd. (1999: 107-108), literatürde faaliyet riskinin değer ilişkisine etkisi konusunda iki temel önermenin bulunduğunu belirtmektedirler. Birincisi, sermaye yoğun firmalarda, sabit maliyetlerin toplam maliyetler içindeki payını gösteren faaliyet kaldıracı yüksek olduğundan, karların volatilitesi yüksektir. Bu nedenle hisse senedi değerlemesinde faaliyet riski yüksek olan firmalar için, defter değerinin öneminin fazla olması beklenmektedir. Diğer yandan sermaye yoğun endüstrilerde piyasaya giriş şartlarının zorluğu rekabeti azaltmaktadır. Böylece firmaların pazar payları istikrarlıdır ve firmalar piyasada güçlüdür. $\mathrm{Bu}$ durum karların daha sürekli olmasını sağladığından, hisse senedi değerlemesinde karların öneminin yüksek olması beklenmektedir.

Aynı şekilde faaliyet riskinin karların sürekliliğine ve gelecek nakit akışlarının tahmin edilebilirliğine etkisi de iki şekilde gerçekleşebilmektedir. Baginski vd. (1999: 107-108), yukarıdaki gerekçelere ek olarak sermaye yoğun endüstrilerin, genellikle dayanıklı tüketim malları ya da yüksek teknoloji içeren hizmetler sunduklarından bu firmaların mal ve hizmetlerine olan talebin yapısının daha oynak olduğunu ve karların sürekliliğinden bahsetmenin söz konusu olamayacağını belirtmektedirler. Aynı şekilde bu firmalarda nakit akışlarının tahmin edilmesi de güçleşmektir. Öte yandan sermaye yoğun endüstrilerde, piyasaya giriş şartlarının zorluğu rekabeti azalttığından firmaların pazar payları istikrarlıdır ve firmalar piyasada güçlüdür. $\mathrm{Bu}$ durum, karların daha sürekli 
olmasını sağlayabilmekte ve dolayısıyla gelecek nakit akışlarının tahmin edilebilirliği artmaktadır.

\section{Kar/Zarar Açıklamaları}

Firmaların zarar açıklamaları, muhasebe bilgilerinin değer ilişkisini olumsuz yönde etkilemektedir. Hayn (1995), zarar açıklayan firmalarda muhasebe bilgilerinin değer ilişkisinin, kar açıklayan firmalara göre daha düşük olduğunu öne sürmektedir. Basu (1997), Elliot ve Hanna (1996), zarar açıklayan firmalarda karların öneminin azaldığına ve defter değerinin öneminin arttığına dair kanıtlar sunmaktadırlar. Zarar açıklayan firmalarda karların sürekliliği ve gelecek dönem karlarıyla arasındaki ilişki bozulmaktadır.

\section{SONUÇ}

Muhasebe bilgilerinin kalitesi birçok açıdan önemli bir konudur. Kaliteli muhasebe bilgileri, öncelikle bilgi kullanıcılarının doğru bilgilendirilmesini sağlayarak, kararlarının isabetli olmasını sağlamaktadır. Piyasalarda asimetrik bilgi problemlerini azaltarak, menkul kıymetlerin doğru fiyatlandırılmasına ve piyasaların etkin işlemesine yardımcı olmaktadır. Böylece bir yandan ekonomik kaynakların israf edilmesinin önüne geçerken, diğer yandan katılımcıların sisteme olan güvenini tesis ederek, uzun vadede sistemin gelişmesine katkıda bulunmaktadir.

$\mathrm{Bu}$ çalı̧̧mada muhasebe bilgilerinin kalitesini etkileyen faktörler üzerine bir literatür incelemesi gerçekleştirilmiştir. Söz konusu faktörler, ülkelere özgü ve işletmelere özgü faktörler olmak üzere ikiye ayrılmıştır. Sonuç olarak;

ᄉ finansal raporların bilgi amaçlı hazırlandığı ülkelerde, vergi amaçlı hazırlandığı ülkelere göre,

ᄉ yatırımcı (ortaklık) haklarının yüksek düzeyde korunduğu ülkelerde, kreditör haklarının yüksek düzeyde korunduğu ülkelere göre,

A gelişmiş sermaye piyasalarına sahip ülkelerde, bankacılık piyasalarının ön planda olduğu ülkelere göre,

A uluslararası muhasebe standartlarının kullanıldığı ülkelerde, bu standartların kullanılmadığı ülkelere göre sundukları muhasebe bilgilerinin daha kaliteli olduğunu söylemek mümkündür.

Ayrıca yozlaşmış politik sistemler, rüşvet verme eğiliminin yüksek olması, özel mülkiyet hakkının devlet müdahalesi tehlikesi altında bulunması ve muhasebe uygulamaları ile vergi düzenlemeleri arasında yakın ilişkinin varlığ 1 gibi faktörler muhasebe bilgilerinin kalitesini olumsuz yönde etkilemektedir.

İşletmelere özgü faktörlerin muhasebe bilgilerinin kalitesi üzerindeki etkilerine ilişkin teorik yaklaşımlar ve ampirik sonuçlar arasında bir görüş̧ birliğinin mevcut olmadığı görülmüştür. Bu nedenle bu faktörlerin etkileri üzerine ampirik çalışmaların arttırılması gerekmektedir.

Genel bir değerlendirme yapıldığında, muhasebe bilgilerinin sunulduğu finansal raporların vergi ekseninden, kullanıcılara bilgi sağlama eksenine doğru yönlendirilmesi, yatırımcı haklarını koruyan yasal mevzuatların geliştirilmesi, sermaye piyasalarındaki düzenleyici ve denetleyici tedbirlerin revize edilmesiyle piyasaların derinliğinin ve genişliğinin arttırılması, uluslararası muhasebe 
standartlarında meydana gelen değişikliklerin takip edilmesi, özel mülkiyet hakkının korunması, toplumsal düzende ve iş hayatında evrensel hukuk ve etik ilkelere uyulmasının sağlanması gibi çabalarla muhasebe bilgilerinin kalitesi arttır1labileceği görülmektedir.

\section{KAYNAKÇA}

Akdoğan, N. ve N. Tenker (2006). Finansal Tablolar ve Mali Analiz Teknikleri. 10. Bask1. Gazi Kitabevi: Ankara.

Akgül, B.A. ve H. Akay (2004). Uluslararası Muhasebe Standartları ve Türkiye'de Uygulama Etkinliğine Illişkin Bir Araştırma. Türkmen Kitabevi: İstanbul.

Aktaş, H. (2009). Hisse Senetleri Piyasasında Muhasebe Bilgilerinin Önemi: IMKKB'de Değer Ilişskisi Analizi. Gazi Kitabevi, Ankara.

Aktaş, R. (2013). Muhasebe Politikalarl, Tahminler ve Hatalar. Gazi Kitabevi: Ankara.

Aktaş, R. and S. Karğın (2012). Predictive Ability of Earnings and Cash Flows: Evidence from Turkish Firms' Cash Flow Statements Prepared by IAS 7. Journal of Money, Investment and Banking, 25: 171-180.

Baginski, S.P., K.S. Lorek, G.L. Willinger and B.C. Branson (1999). The Relationship Between Economic Characteristics and Alternative Annual Earnings Persistence Measures. The Accounting Review, 74(1): 105-120.

Barth, M.E, W.R. Landsman and M.H. Lang (2008). International Accounting Standards and Accounting Quality. Journal of Accounting Research, 46(3): 467-498.

Basu, S. (1997). The Conservatism Principle and the Asymetric Timeliness of Earnings. Journal of Accounting and Economics, 24: 3-37.

Başpınar, Ahmet. (2004), Türkiye'de ve Dünya'da Muhasebe Standartlarının Oluşumuna Genel Bir Bakış. Maliye Dergisi, 146.

Bostanc1, S. (2002). Küreselleşen Muhasebede Standartlaşma ve Türkiye Muhasebe Standartları Kurulu. Mali Çözüm, 59.

Brimble, M. and A. Hodgson (2007). On the Intertemporal Value Relevance of Conventional Financial Accounting in Australia. Accounting and Finance, 47(4): 599-622.

Cascino, S., A. Pugliese, D. Mussolino and C. Sansone (2010). The Influence of Family Ownership on the Quality of Accounting Information. Family Business Review, 20(10): 1-20.

Ceylan, A. ve T. Korkmaz (2006). Issletmelerde Finansal Yönetim. Ekin Kitabevi: Bursa.

Chandrapala, P. (2013). The Value Relevance of Earnings and Book Value: The Importance of Ownership Concentration and Firm Size. Journal of Competitiveness, 5(2): 98-107.

Collins, D.W., E.L. Maydew and I.S. Weiss (1997). Changes in the Value-relevance of Earnings and Book Values over the Past Forty Years. Journal of Accounting and Economics, 24: 39-67.

Deloitte (2012). IFRSs in Your Pocket 2012. https://www.iasplus.com/en/publications/global/ifrsin-your-pocket/ifrss-in-your-pocket-2012 (Erişim: Mayıs 2013).

Demir, B. (2010). Muhasebe Bilgi Sistemlerinde Bilgi Kalitesi. Muhasebe ve Finansman Dergisi, 48: 142-153.

Elliott, J. and J. Hanna (1996). Repeated Accounting Write-offs and the Information Content of Earnings. Journal of Accounting Research, 34: 135-155.

Fan, J.P.H. and T.J. Wong (2002). Corporate Ownership Structure and The Informativeness of Accounting Earnings in East Asia. Journal of Accounting and Economics, 33: 401-425.

Gençoğlu, Ü.G. (2007). Türkiye Muhasebe Standartlart ve Uygulamalar. Türkmen Kitabevi: İstanbul.

Gençoğlu, Ü.G. ve Y. Ertan (2012). Muhasebe Kalitesini Etkileyen Faktörler ve Türkiye'deki Durum. Muhasebe ve Finansman Dergisi, 53: 1-24.

Gökçen, G., B.A. Akgül ve C. Çakıcı (2006). Türkiye Muhasebe Standartları Uygulamaları. Beta Basım: İstanbul.

Gökdeniz, A.Ü. (t.y.). Muhasebe Uygulamalarındaki Uluslararası Farklılıklar ve Çözüm Önerisi. Avciol Basim: İstanbul. 
Han, S.S. (2005). Ownership Structure and Quality of Financial Reporting. http://citeseerx.ist.psu.edu/viewdoc/download?doi=10.1.1.202.1600\&rep=rep1\&type=pdf

Hayn, C. (1995). The Information Content of Losses. Journal of Accounting and Economics, 20(2): 125-153.

Hodgson, A. and P.S. Clarke (2000). Earnings, Cash Flows and Returns: Functional Relations and the Impact of Firm Size. Accounting and Finance, 40(1): 51-73.

Holthausen, R.W. (2008). Accounting Quality, Financial Reporting Outcomes and Enforcement. Journal of Accounting Research, doi: 10.1111/j.1475-679X.2009.00330.x

Isidro, H. and I. Raonic (2012). Firm Incentives, Institutional Complexity and The Quality of "Harmonized" Accounting Numbers. The International Journal of Accounting, 47: 407436.

Jun-bo, S. and Y. Hai-zhong (2011). Analysis of Accounting Disclosure Quality in Capital Markets: Current Situation and Impact Factors. Management Science and Industrial Engineering (MSIE), 2011 International Conference on, 8-11 Jan. 2011, Harbin, 699-703.

Kamu Gözetimi, Muhasebe ve Denetim Standartları Kurumu. Finansal Raporlamaya İlişkin Kavramsal Çerçeve. TMS/TFRS 2013 Seti.

Karğın, M. ve N. Demirel Arıcı (2015). Muhasebe Bilgilerinin Kalitesini Ölçmeye Yönelik Bir Çalışma: Borsa İstanbul Örneği. Muhasebe ve Finansman Dergisi, 67: 1-21.

Okka, O. (2005). Finansal Yönetime Giriş. Nobel Kitabevi: Ankara.

Örten, R., H. Kaval ve A. Karapınar. (2008). Türkiye Muhasebe-Finansal Raporlama Standartları, Uygulama ve Yorumları. Gazi Kitabevi: Ankara.

Sayılgan, G. (2006). Soru ve Yanıtlarla Isşetme Finansmanı. Turhan Kitabevi: Ankara.

Shirazipour, M., E. Yaghoubi and M. Mohammadi (2013). Investigation of the Affected Factors of Earnings Persistency in the Firms Listed in Tehran Stock Exchange. Journal of Basic and Applied Scientific Research, 3(6): 753-759.

Soderstrom, N.S. and K.J. Sun (2007). IFRS Adoption and Accounting Quality: A Review. European Accounting Review, 16(4): 675-702.

VİKIPEDİ, http://tr.wikipedia.org/wiki/Hukuk (Erişim: Eylül 2013).

Wang, D. (2006). Founding Family Ownership and Earnings Quality. Journal of Accounting Research, 44(3): 619-656.

Yallapragada, R.R. (2012). Incorporating International Financial Reporting Standards into the United States Financial Reporting System: Timeline and Implications. International Business \& Economics Research Journal, 11(3): 283-290.

\section{SUMMARY}

Accounting quality is a broad concept that is difficult to be stated with unique and generally accepted definition. It has various dimensions and measures in accounting literature. However, IASB dealt with the concept from a utilitarian approach. In other words, if accounting provides useful information to users in their decision making process, then it is well-qualified. Qualitative characteristics that are useful in terms of accounting information need to be addressed in Conceptual Framework by two groups such as fundamental (relevance and faithful representation) and enhancing (comparability, verifiability, timeliness, and understandability) ones. The fundamental qualitative characteristics are relevance and faithful representation. Relevant financial information is capable of making a difference in the economic decisions made by users. Faithful representation expresses that accounting information should be complete, neutral and free from error. Enhancing qualitative characteristics are comparability, 
verifiability, timeliness, and understandability. These characteristics enhance the usefulness of accounting information which are relevant and represented faithfully.

The aim of this study is to analyze the determinants of accounting quality. For this purpose, a literature review is executed on the subject. In this study, the determinants of accounting quality are classified by country specific factors and firm specific factors.

Country specific factors include legal and political systems, accounting standards, financial market development and tax system. Legal systems are mainly classified by two groups such as common law and code law systems in the world. In common law countries, the role of accounting is providing information to investors. These countries protect shareholders strongly and have developed capital markets. In code law countries, tax-based financial reporting is in the forefront. These countries have high creditor protection and banks are dominant in financial markets. So accounting quality is higher in countries have;

$\lambda$ information-based financial reporting than countries have tax-based financial reporting,

A strong shareholder protection than countries have strong creditor protection,

ᄉ high level developed capital markets than countries have developed banking systems,

A mandatory adoption of international financial reporting standards than countries use national financial reporting standards.

In addition rent-seeking political systems, high level corruption and bribe, higher levels of government expropriation on private property rights, accounting practices engage with tax regulation affect accounting quality negatively.

Firm specific factors include capital structure, ownership pattern, firm size, financial risk (leverage), operational risk and profit/loss disclosure. There are various theoretic approaches on the impact of firm specific factors on accounting quality. Also different results have presented in empirical studies. Therefore, more studies should be done on firm specific factors.

When it is evaluated generally, accounting quality can be increased by preparing information-based financial reports, making regulations that protect shareholders' rights, developing capital markets, following changes in international financial reporting standards, protecting right of private property, enabling to respect universal law and ethical rules in social order and business life. 